\title{
Flood Vulnerability Analysis Using Remote Sensing and GIS: A Case Study of Sidoarjo Regency
}

\author{
Hery Setiawan Purnawali ${ }^{1 *}$, Teguh Hariyanto ${ }^{1}$, Danar Guruh Pratomo ${ }^{1}$ and Nurin Hidayati ${ }^{2}$ \\ ${ }^{I}$ Department of Geomatics Engineering, Institut Teknologi Sepuluh Nopember (ITS) Surabaya \\ ${ }^{2}$ Department of Marine Science, Faculty of Fisheries and Marine Science, Brawijaya University \\ *Corresponding author: hery.sp.plano@gmail.com
}

\begin{abstract}
Sidoarjo Regency is one of the regencieslocatedin East Java Province Indonesia.Topography of some area in Sidoarjocan be categorized asin low altitude topography, so it makes this regency haspotential risk for flood disaster. Flood incident in Sidoarjo occurs almost every year. The cause of flooding in this district is an accumulation of several factors, such as heavy rainfall in the rainy season for every year, the low altitude areas in several sub-districts, land cover dominated roads and buildings in the some sub-districts, and the existence of several rivers flowing through the district. Application of Geographic Information System (GIS) and remote sensing is generated in this study to present information on the mapping of flood vulnerability zones in Sidoarjo. Integration of satellite and GIS datasets are carried out to prepare the flood zonation mapping of Sidoarjo Regency. Rainfall data fromTropical Rainfall Measuring Mission (TRMM), topographic map, land coverand the distance to main channel data are the datasetsused to identify the flood vulnerability. Flood vulnerability information includes the spatial distribution of flood hazard vulnerability in all sub-districs of Sidoarjo Regency. Spatial information is represented in the form of a map image. By knowing the spatial distribution, it can be known the level of vulnerability of areas to flooding. Most of Sidoarjo regency is flood vulnerable area, which is $\mathbf{7 6 . 2 4 \%}$ or $\mathbf{6 5 8 , 7 0 2 , 7 1 9 . 9 1 ~ s q m}$. It consist of $33.14 \%$ very high vulnerable area and 43.10\% high vulnerable area. Very high vulnerable flood-prone areas in Sidoarjo Regency include most area of Jabon, Porong, Tanggulangin, Balongbendo, Krembung, Taman, and Waru sub-districts, while others are some parts of Candi, Sidoarjo, Buduran, and Gedangan sub-districts. High vulnerable flood-prone area include Tarik, Prambon, Tulangan, Wonoayu, and Sukodono sub-districts. The most dominant factors causing flooding in Sidoarjo Regency is the change of land cover, heavy rainfall, and high drainage density, while other factor also contributing to future flood vulnerability are land subsidence.
\end{abstract}

Keywords—flood, Sidoarjo, GIS, Remote Sensing

\section{INTRODUCTION}

The he area of Sidoarjo Regency is formed from alluvial

sedimentation process of beach and river delta and its relief form combination of terrain and bumpy terrain. In 1969 the area of Sidoarjo Regency planned as a technical irrigation area with an area of about 26,000 ha. However, by building the area of Sidoarjo Regency into an industrial area, the area of rice fields is reduced because some of the rice fields are made into residential and industrial areas. Construction of buildings, highways and other supporting facilities buildings are not balanced with the construction of adequate facilities and infrastructure drainage. This can be a response to conservation area response to lower and faster rainwater inputs than inundation [1].

The rainy season is almost a problem in many regions. News about flooding during the rainy season has always been a topic in some social media. In Sidoarjo Regency, the problem of flooding has always been a problem throughout the year. From the data of BNPB [2], flood is the most frequent natural disaster in Sidoarjo. Floods occur almost every year during the rainy season.

Planning development in flood prone areas that are very mature is very necessary in order to minimize the impacts. One example of the flood accident in Sidoarjo is in 2016, due to floods that destroyed some areas in Sidoarjo and railway line in Porong, Sidoarjo. Due to floods that occured for several days, PT KAI Daop VIII Surabaya suffered a loss of 1.6 billion. The calculation of the results based on the average daily productive potential of 3-4 billion, so it can be calculated losses during the several days of the flood.Some losses cultivated from ticket cancellation, cancellation of trips several rail routes, the transfer of mode of transportation by bus with rate of 10 buses per day, and improvement of infrastructure around the railroads [3].

An important step to identify the level of flood vulnerability is to map the flood-prone areas to a level. This mapping is very important to be done in the determination of various development policies, such as the development of conservation land, the opening and placement of settlement land, the making of embankments, and other policies. Mapping is done with attention to spatial and temporal precision. Spatial data is needed to know the distribution of flood area, while the temporal data is needed to know the flood period in Sidoarjo Regency. Geographical Information Systems (GIS) and Remote Sensing as a science and technology, able to provide a form of management and data of spatial analysis in large numbers. GIS can be utilized to determine the model with selected data so that the views and knowledge of users about the developing situation within, and with GIS mapping of flood prone areas can 
be done. The existence of this system is expected later flood hazard level in Sidoarjo Regency can be mapped and can be predicted until 10 years ahead. Remote sensing and GIS are used operationally for early warning and decision support systems for authorities during disaster [4] [5].

The purposes of this research are to creating basic data based on Geographic Information System (GIS) for flood vulnerable mapping in Sidoarjo Regency, to mapping vulnerable flood areas based on flood vulnerability parameters in Sidoarjo Regency. So, from this research will be known about the main causes of flood disaster and flood-prone areas in Sidoarjo Regency.

\section{METHOD}

The area in this study covers all areas of Sidoarjo Regency. This regency consists of 18 sub-districts, they are Sidoarjo City, Balongbendo, Buduran, Candi, Gedangan, Jabon, Krembung, Krian, Prambon, Porong, Sedati, Sukodono, Taman, Tanggulangin, Pull, Tulangan, Waru and Wonoayu (Figure 1).

\subsection{Data and Procedures}

This study covers all activities related to vulnerability analysis of Sidoarjo Regency to the flood hazard. The data used in this research is divided into 2 (two) types based on data sources that are primary data and secondary data. Primary data is data obtained from field observation, including observation of all districts in Sidoarjo Regency and its documentation, while secondary data is obtained from satellite image data and related institution. List the necessary data along with the source as in Table 1. The detailed methodology to be adopted for the study is given in Figure 2.

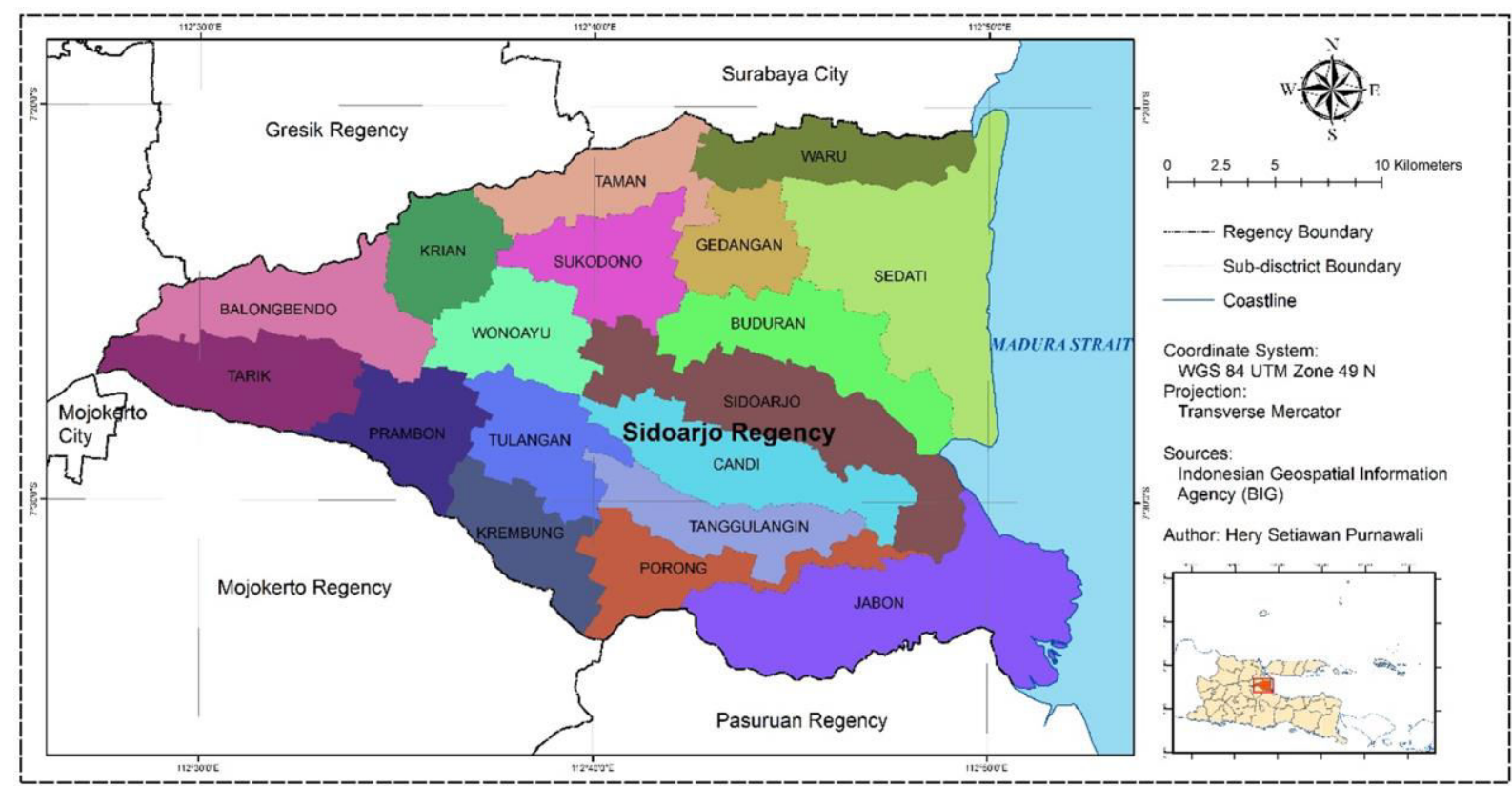

Figure 1. Map of Sidoarjo Regency

Table 1. Parameters and data sources

\begin{tabular}{|c|c|c|}
\hline Data & Spesification & Source \\
\hline Topography & Scale $1: 25,000$ & $\begin{array}{l}\text { Indonesian Topography (RBI) Map from Geospatial Information Agency } \\
\text { (BIG) }\end{array}$ \\
\hline Land Cover & Scale $1: 25,000$ & $\begin{array}{l}\text { Indonesian Topography (RBI) Map from Geospatial Information Agency } \\
\text { (BIG) and Landsat } 8\end{array}$ \\
\hline Rainfall & $\begin{array}{l}\text { Averaged Rainfall Data } \\
(2007-2017)\end{array}$ & $\begin{array}{l}\text { Tropical Rainfall Measuring Mission (TRMM) Data from website: } \\
\text { http://giovanni.sci.gsfc.nasa.gov }\end{array}$ \\
\hline Drainage Density & Scale $1: 25,000$ & $\begin{array}{l}\text { Indonesian Topography (RBI) Map from Geospatial Information Agency } \\
\text { (BIG) }\end{array}$ \\
\hline Land Subsidence & $\begin{array}{l}\text { Averaged Land } \\
\text { Subsidence data (2010- } \\
\text { 2016) }\end{array}$ & $\begin{array}{l}\text { Field Survey and Secodary Data from Report on Land Subsidence Study in } \\
\text { Tanggulangin and Surrounding Areas of Sidoarjo Regency by Haryanto et } \\
\text { al. (2016) [6] }\end{array}$ \\
\hline
\end{tabular}




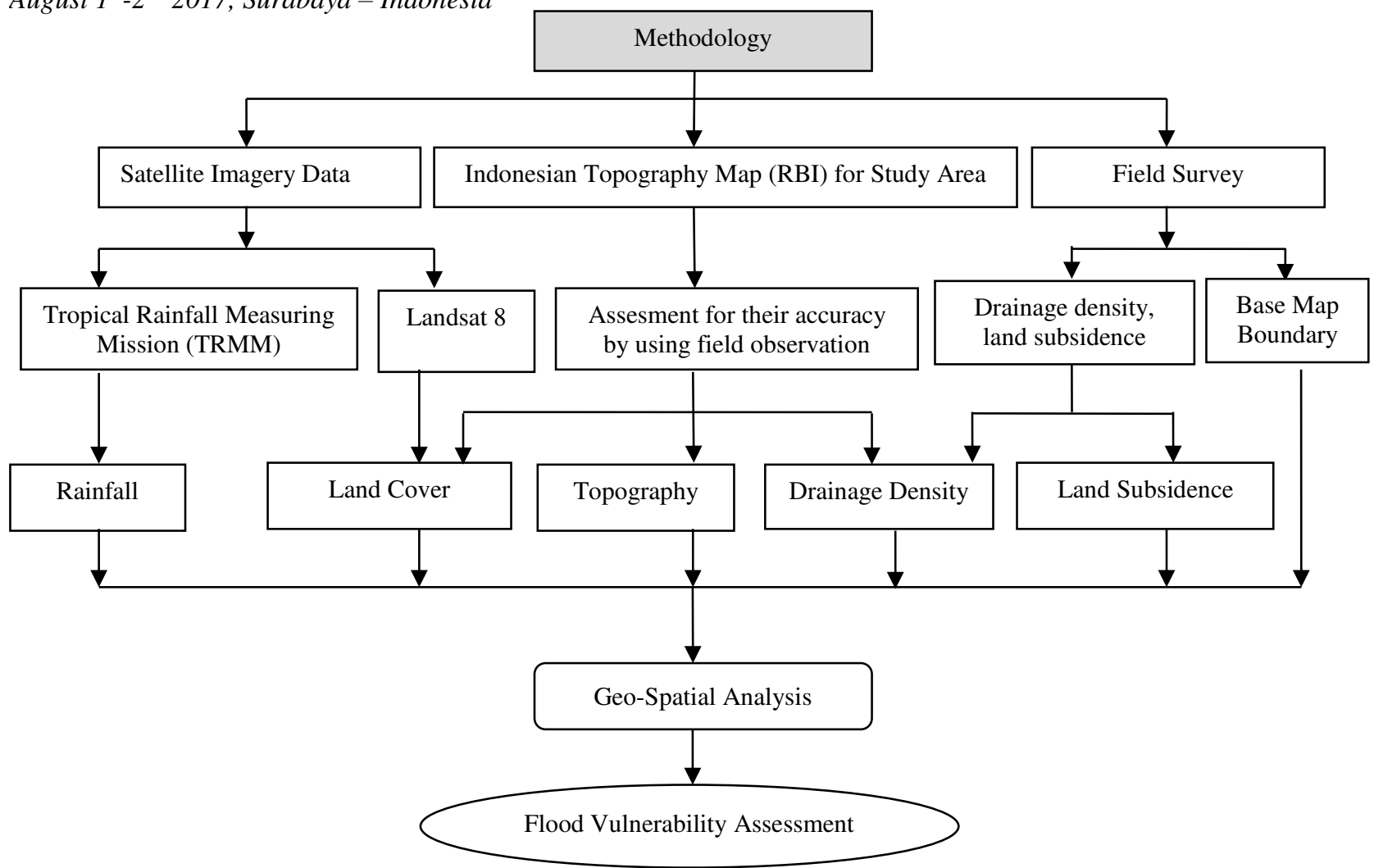

Figure 2. Research Methodology

\subsection{Flood Vulnerability Variable}

\subsubsection{Rainfall}

Floods are related to extreme in precipitation. A combination of precipitation characteristics influences the flood events. Flash floods relatively small conventional activity have received much attention and are deemed characteristic of small to medium basins [7].

Rainfall classification standard used in this research based on Indonesian Meteorology Climatology and Geophysics Council [8], as shown in Table 2.

Table 2. Rainfall Classification [8]

\begin{tabular}{cc}
\hline $\begin{array}{c}\text { Rainfall Intensity } \\
(\mathrm{mm} / \text { day })\end{array}$ & Description \\
\hline$<5$ & Very light rain \\
$5-20$ & Light rain \\
$20-50$ & Moderate rain \\
$50-100$ & Heavy rain \\
$>100$ & Very heavy \\
\hline
\end{tabular}

\subsubsection{Drainage Density}

Drainage density is the length of all channel within the basin divided by the area of the basin. If the drainage network is dense at any area, it will be a good indicator to high flow accumulation path and more likely to get flooded [5]. Then, drainage density classification are as in Table 3.
Table 3. Drainage Density Classification [7]

\begin{tabular}{ll}
\hline Drainage Density $\left(\mathrm{m} / \mathrm{m}^{2}\right)$ & Description \\
\hline$<0.001434$ & Least dense \\
$0.001434-0.002869$ & Light dense \\
$0.002869-0.004305$ & Moderate dense \\
$0.004305-0.005740$ & Dense \\
$>0.005740$ & Very dense \\
\hline
\end{tabular}

and is generally classified by the amount and type of vegetation, which is a reflection of its use, environment, cultivation and seasonal phenology. Land cover is othe essential influences on runoff (Elkhracy 2015). Land cover classification standard being used in this research was based on [9], Table 4.

Table 4. Land Cover Classification [9]

\begin{tabular}{|c|c|}
\hline Land Cover & Description \\
\hline $\begin{array}{l}\text { Urban or Built-up } \\
\text { Land }\end{array}$ & $\begin{array}{l}\text { Area with much of the land covered by } \\
\text { structures, including residential, } \\
\text { industrial land and other facilites }\end{array}$ \\
\hline $\begin{array}{l}\text { Agricultural Land } \\
\text { - Rice Field }\end{array}$ & $\begin{array}{l}\text { Area covered with land used primarily } \\
\text { for production of food and fiber, } \\
\text { including rice field }\end{array}$ \\
\hline Water & $\begin{array}{l}\text { Area covered with water such as river } \\
\text { and lake }\end{array}$ \\
\hline Wetland & $\begin{array}{l}\text { Area where the water table is at, near, } \\
\text { or above the land surface for a } \\
\text { significant part of most years, } \\
\text { including fish ponds }\end{array}$ \\
\hline
\end{tabular}

L.L.4. SIOpe

Slope is the ratio of steepness or the degree of inclination of a feature relative to the horizontal plane. 
Gradient, grade, incline and pitch are used interchangeable with slope. Slope is typically expressed as a percentage, an angle, or a ratio. The average slope of a terrain feature can conveniently be calculated from contour lines on a topo map. To find the slope of a feature, the horizontal distance (run) as well as the vertical distance (rise) between two points on a line parallel to the feature need to be determined. The slope is obtained by dividing the rise over run. Multiply this ratio by 100 to express slope as a percentage. The slope angle expressed in degrees is found by taking the arctangent of the ratio between rise and run [10]. Slope classes used in this research was defined as in Table 5.

Slope data in this research was generated from satellite image from Advanced Spaceborne Thermal Emission and Reflection Radiometer (ASTER) Global Digital Elevation Model Version 2 (GDEM V2).

\subsubsection{Land Subsidence}

Decrease in the face of the land (land subsidence) that occurs from year to year will affect the magnitude of the potential flood of a region. Porong sub-district is one of the areas in Sidoarjo regency with a high level of land subsidence due to Lapindo mudflow. The scores on each class of land subsidence are based on the range of the amount of land subsidence in Sidoarjo. The classification of land subsidence based on existing phenomena in the study area, its relation to the impact of land subsidence with potential flood potencies.

\section{RESULTS AND DISCUSSION}

From this research will be analised several factors that are the most important parameters caused flood hazard in Sidoarjo Regency, with zonation map of each factors as the final results. The 4 (four) factors main caused of Sidoarjo flooding are rainfall, drainage density, topography and land cover. Floods can be divided into 2 (two) kinds of events ie floods that occur in areas that are usually not flooded and flood events occur due to flood waters from the river because the flood discharge is greater than capacity (Lockwood, 1987 in [12]). Flood event itself is not a problem if it does not interfere with human activities in conducting activities in flood areas. It is necessary to regulate the flood plains, to reduce the loss due to flooding. So in other words flood events will not be a problem or not a natural disaster (natural hazard) when the flood is not disturbing or harmful to humans.

\subsection{Rainfall}

Rainfall in Sidoarjo regency is analyzed based on TRMM 1: 25.000 rainfall data, analyzed for 10 years between 2007 and 2017. Rainfall data is analyzed both temporally and spatially. Temporal distribution of 10 years rainfall, analyzed the peak time of rainfall. This peak time is based on the highest rainfall discharge. Where the high rainfall discharge can potentially cause flooding in the region of Sidoarjo regency. In addition to the temporal analysis, rainfall is also analyzed spatially. From both the analysis (temporal and spatial), we can know the time and flood-prone areas in this district. Spatial distribution of rainfall averaged data in $\mathrm{mm} /$ day.

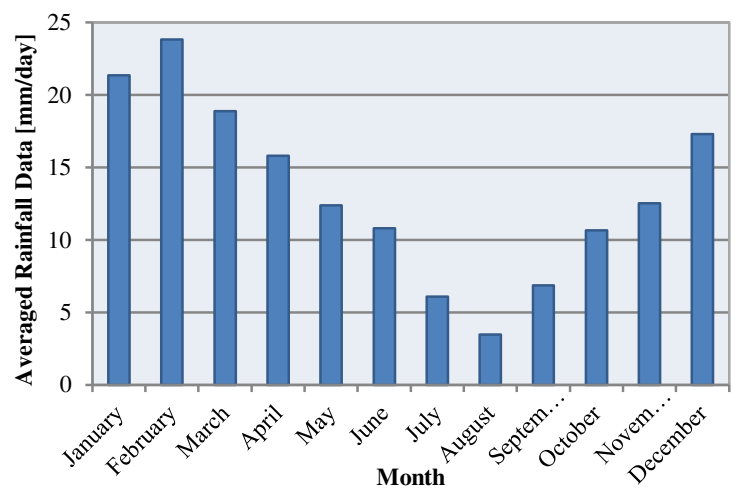

Figure 3. Averaged rainfall data based on monthly distribution

Potential areas for heavy rainfall including several subdistricts in the west of Sidoarjo regency, those are Balongbendo, Tarik, Krian, Wonoayu, Prambon, and Tulangan sub-district with rainfall averaged value of more than $20 \mathrm{~mm} /$ day. Overall the area in sidoarjo included in the category of areas with fairly high rainfall, with averaged value of rainfall more than $18 \mathrm{~mm} /$ day, Figure 4.

\subsection{Slope}

The slopes in Sidoarjo regency range from 0 to $0.5 \%$, 0.5 to $2 \%$, and 2 to $5 \%$. The distribution of the slopes of Sidoarjo Regency can be seen in Figure 5.

The slope of $0-0.5 \%$ in Sidoarjo Regency is mostly located in Sedati and Jabon sub-districts, which is $12 \%$, while in Sidoarjo sub-district is $9 \%$. The percentage of slopes of $0.5-2 \%$ is $13 \%$ in Tarik District, $11 \%$ are in Sedati District, and $10 \%$ are in Balongbendo Subdistrict. While slopes of $2-5 \%$ only exist in 3 areas, namely $62 \%$ are in District Tarik, 32\% in Krian District, and 6\% in District Park.

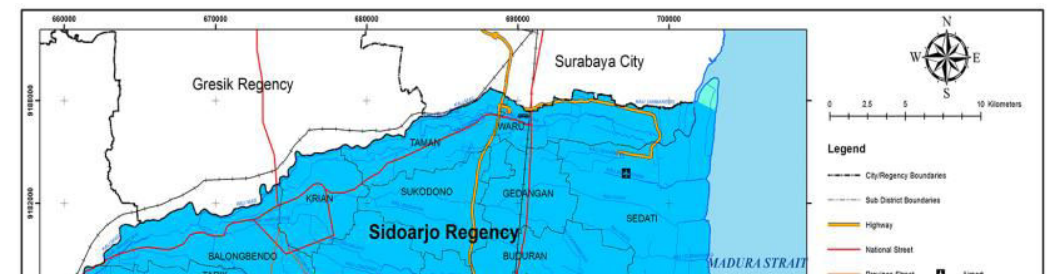




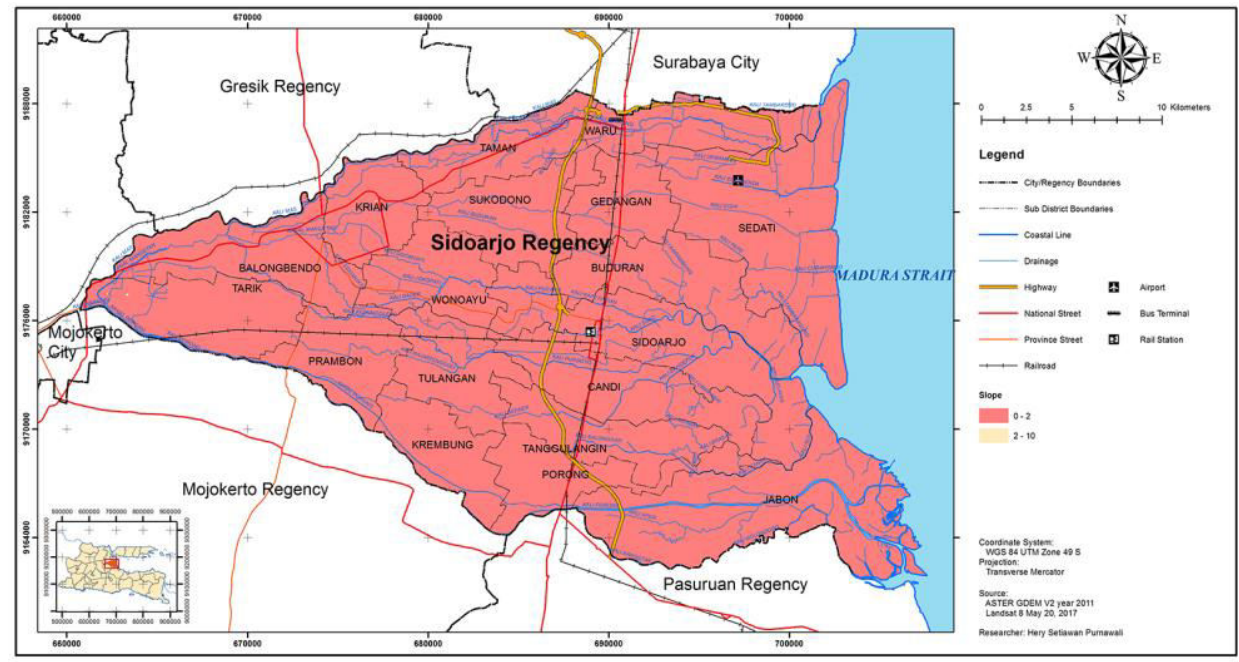

Figure 5. Slope distribution map of Sidoarjo Regency

\subsection{Land Cover}

Land cover of Sidoarjo Regency is identified in several parameters, that Agricultural, Barend Land, Lake, Mangrove, Rangeland, Urban or built up, water, and wetland. Land use will affect flood vulnerability of a region. Land use will play a role in the amount of water runoff resulting from rain that has exceeded the infiltration rate. Areas overgrown by trees will be difficult to drain the runoff water. This is due to the large water absorption capacity of the trees and the slow runoff flow due to being retained by roots and tree trunks, so the possibility of flooding is smaller than areas not planted by vegetation. Land cover map of Sidoarjo Regency was generated from Indonesian Land Cover map (RBI) issued by Indonesian Geospatial Agency (BIG) which was also being updated by using a satellite image of Landsat 8 year 2016.

The land cover of Sidoarjo is dominated mostly by agriculture, formed in many paddy fields at the western part. While Wetland is the second dominated land use, and located at the eastern coastal area, formed in many fish ponds, especially Bandeng. The middle part, was dominated by urban or built-up building. High density settlements are located at the norther part, such as at Sub-district Waru and Taman. At the center part, subdistrict Sidoarjo, was dominated by high density settlements and also most of government facilities and shopping malls.

At the northern part, also located an international airport, and joint operation terminal with neighbourhood city, Surabaya. At the southern part, at sub-district Porong, located an active mud volcano. Detailed land cover of Sidoarjo Regency as a map shown in Figure 6.

\subsection{Drainage Density}

Sidoarjo Regency was also well known as delta city, surrounded by two big rivers, Kali Surabaya at the north which flows and Kali Porong at the south. At the middle part, although not as big as previous rivers, but has also a significant river, Kali Sidokare. Kali Porong has an important role too as an exit spillway of mud from Porong Mud volcano. River in Sidoarjo, usually overflow during rainy seasons and cause several flooded area. Detailed drainage and rivers of Sidoarjo Regency as a map shown in Figure 7. In Figure 8 shows the distance of main channel in Sidoarjo Regency.

The river buffer is an area of a certain width depicted around the river at a certain distance. River buffers are based on logic and knowledge of river relationships and flood events. Assuming the closer to the river, the chances of a flood are higher.

The river buffer map is based on the buffer zone of the river resulting from the clustering of the flood vulnerability of an area based on the distance to the river. 
The buffer limit is based on predetermined criteria based on the approximate level of vulnerability of areas near

the river to floods.

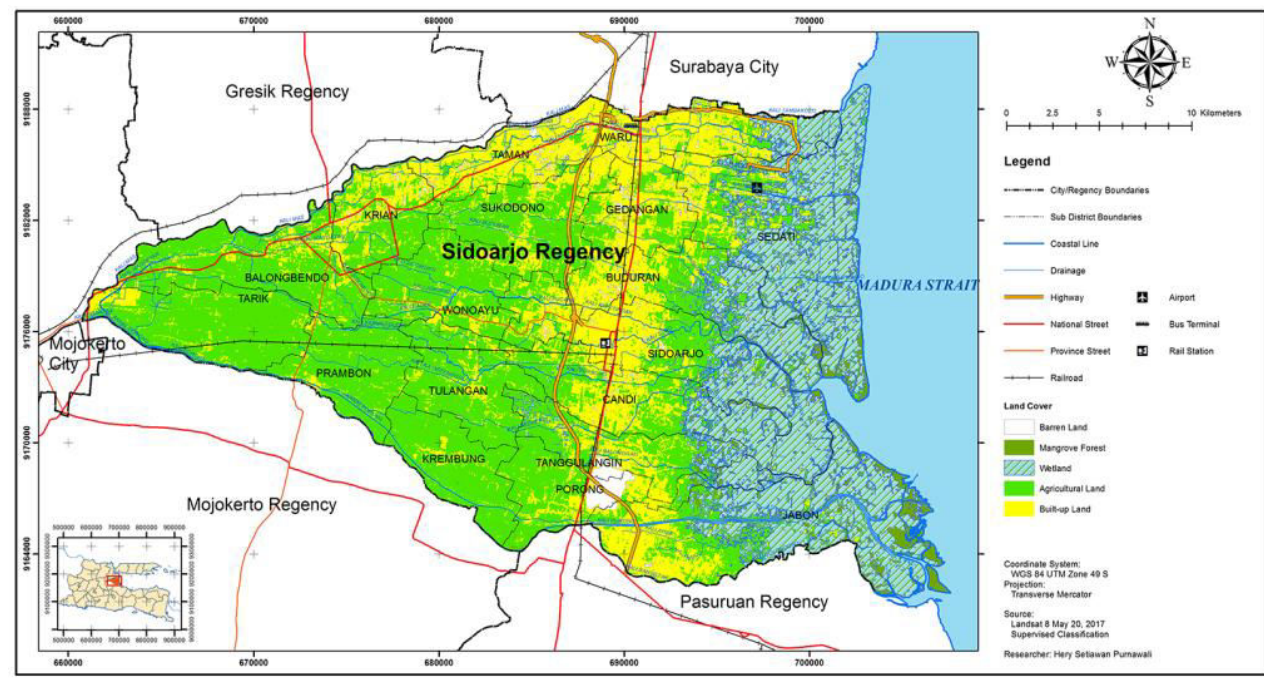

Figure 6. Land cover of Sidoarjo Regency

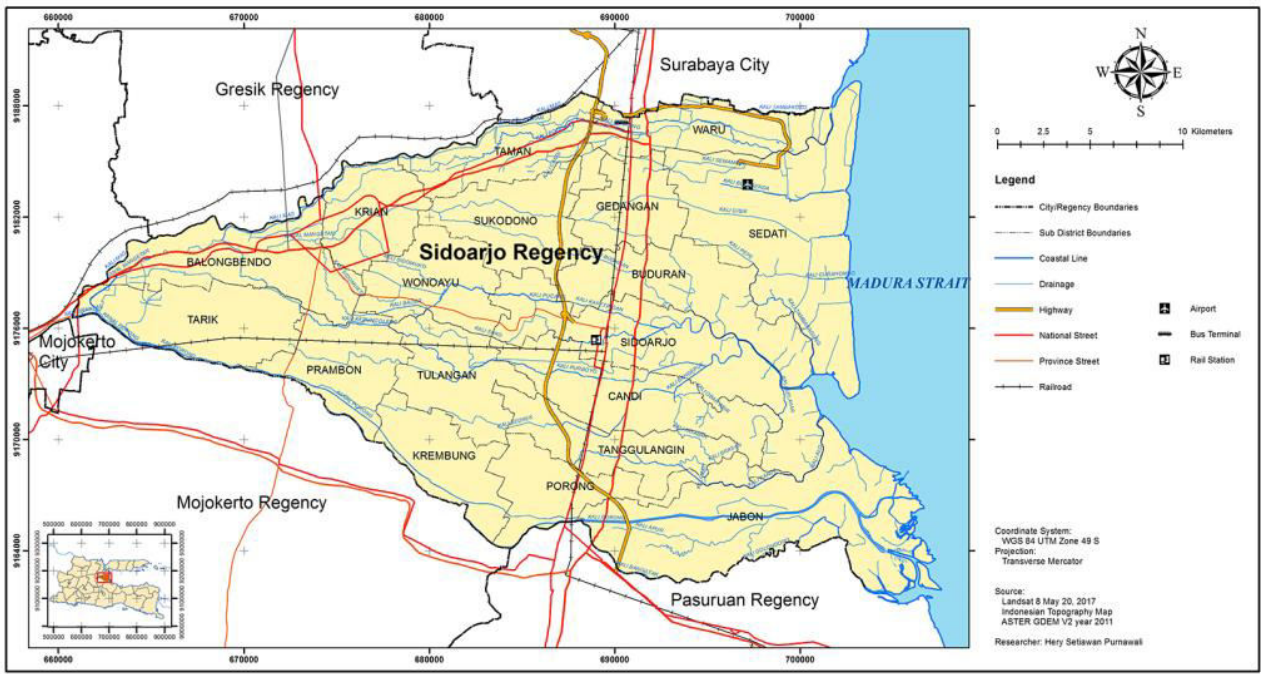

Figure 7. Drainage density in Sidoarjo Regency

\subsection{Land Subsidence}

Land subsidence data in Sidoarjo Regency is based on the secondary data from research report of the Study Team of the Center for Disaster Study of Research and Community Service (LPPM), Institut Teknologi Sepuluh Nopember (ITS) Surabaya, comparing the height of land elevation in 2016 and the previous year in 2010. Which then can be known magnitude on the existing land. Based on the measurement results, it can be seen that the distribution of land subsidence mostly occurs in the surrounding area of Sidoarjo Mud. More information can be seen in Figure 8.

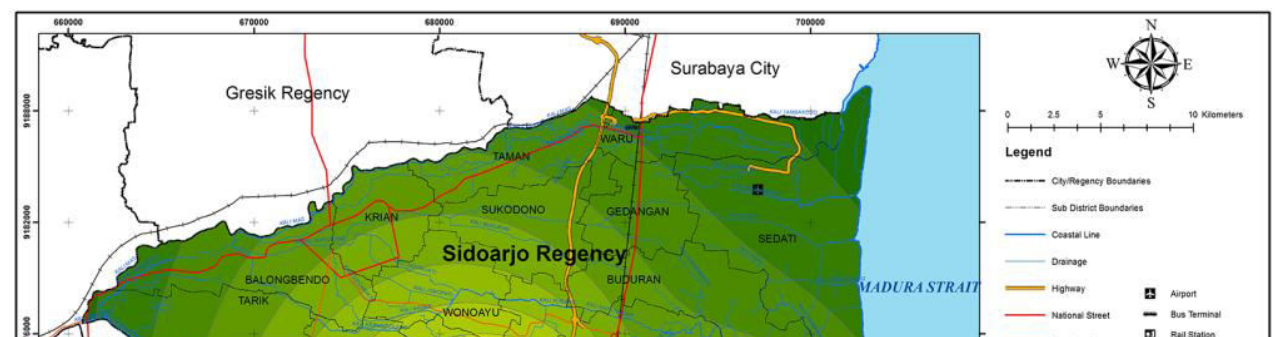




\subsection{Analytical Hierarchy Process (AHP)}

AHP is a decision support model that describes complex multi-factor or multi-criteria problems into a hierarchy, developed by Thomas L. Saaty [13]. Saaty define hierarchy as a representation of a complex problem in a multi-level structure where the first level is the goal, which follows the level, criteria, sub-criteria, and so on. AHP is often used as a method for the following reasons:

a. Hierarchical structure, as a consequence of the selected criteria, to the deepest sub-criteria

b. Takes into account the validity up to the limit of inconsistency tolerance of the various criteria and alternatives chosen by the decision

c. Take into account durability

The basic concept of AHP is the use of pairwise comparison matrices to generate relative weight values between criteria and alternatives. A criterion is compared to other criteria in terms of how important it is to the attainment of the above objectives [13]. The main equipment of AHP is a functional hierarchy with the main input of human perception. The existence of a hierarchy allows breaking down of complex or unstructured problems in subparts, then compiling them into a hierarchical form (Table 6).

Assessment for comparison between one criterion with another criterion is free of one another so that this can lead to inconsistency. The output of AHP has to be consistent for all the pairwise comparisons measured by Consistency Index (CI) and Consistency Ratio (CR). The CI follows Equation by Saaty [14]; where $\mathrm{n}$ is a number of parameters.

where:

$$
C I=\frac{\left(\lambda_{\max }-n\right)}{(n-1)}
$$

\section{CI : Consistency Index}

$\lambda_{\text {max }}$ : The largest eigenvalues of the " $n$ " order matrix

The largest eigenvalue is obtained by summing the result of multiplication of the number of columns by eigen vector. The limit of inconsistency is measured by using consistency ratio (CR), ie comparison between consistency index (CI) and random generator value (RI). This value depends on the matrix order n. Consistency ratio can be formulated as follows:

$$
C R=\frac{C I}{R I}
$$

Random Index of Consistency (RI) is as shown in Table 7. The final calculation is consistency ratio; it is a ratio of the $\mathrm{CI}$ and random index (RI); RI value for five parameters is 1.12 . The maximum threshold of $\mathrm{CI}$ is $=0.1$ and $\mathrm{CR}=10 \%$; the rational value is when the CI and CR have fulfilled the maximum threshold value.

Tabel 6. Pairwise comparison scale [13]

\begin{tabular}{cll}
\hline Intensity of Importance & Definition & Explanation \\
\hline 1 & $\begin{array}{l}\text { Equal importance } \\
\text { Moderate importance }\end{array}$ & $\begin{array}{l}\text { Two elements contribute equally to the objective } \\
\text { Experience and judgment strongly favor one parameter over } \\
\text { another } \\
\text { Experience and judgment strongly favor one parameter over } \\
\text { another } \\
\text { One parameter is favored very strongly s and is considered superior } \\
\text { to another; its dominance is demonstrated in practice } \\
\text { The evidence favoring one parameter as superior to another is of } \\
\text { the highest possible order of affirmation }\end{array}$ \\
\hline
\end{tabular}

Table 7. Random Index of Consistency (RI)

\begin{tabular}{ccccccccccc}
\hline $\mathrm{n}$ & 1 & 2 & 3 & 4 & 5 & 6 & 7 & 8 & 9 & 10 \\
\hline $\mathrm{RI}$ & 0.00 & 0.00 & 0.58 & 0.90 & 1.12 & 1.24 & 1.32 & 1.41 & 1.45 & 1.49 \\
\hline
\end{tabular}




\subsection{Ranking of Weighted Vulnerability}

Table 8. Weighted flood vulnerability ranking

\begin{tabular}{llll}
\hline Parameter & $\begin{array}{l}\text { Relative } \\
\text { Weighted }\end{array}$ & Reclassified Parameter & Ranking \\
\hline Land & $42 \%$ & Barren land & 1 \\
Cover, LC & & Mangrove forest & 2 \\
[9] & & Wetland & 3 \\
& & Agricultural land & 4 \\
& & Built up land & 5 \\
\hline Rainfall, R & $26 \%$ & $<5$ & 1 \\
(mm/day) & & $5-20$ & 2 \\
[8] & & $20-50$ & 3 \\
& & $50-100$ & 4 \\
& & $>100$ & 5 \\
\hline Drainage & $16 \%$ & $<0.001434$ & 1 \\
Density, & & $0.001434-0.002869$ & 2 \\
DD (m/m $\left.{ }^{2}\right)$ & & $0.002869-0.004305$ & 3 \\
[7] & & $0.004305-0.005740$ & 4 \\
& & $>0.005740$ & 5 \\
\hline Slope,S (\%) & $10 \%$ & $>30$ & 1 \\
{$[11]$} & & $>15-30$ & 2 \\
& & $>10-15$ & 3 \\
& & $>2-10$ & 4 \\
& & $0-2$ & 5 \\
\hline Land & $6 \%$ & $<2.5$ & 2 \\
Subsidence, & & $>2.5-5$ & 3 \\
LS & & $>5-7.5$ & 5 \\
(cm/year) & & $>7.5-10$ & 2 \\
& & $>10$ & 5 \\
\hline & & & 5 \\
\hline
\end{tabular}

\subsection{Ranking of Map Criteria by Analytical Hierarchy} Process (AHP)

The main use of Analytical Hierarchy Process (AHP) is the ranking and prioritization of multi-criteria parameter. Priority framework quality affects the effectiveness of available sources which are the essential judgment from the decision maker. Furthermore, the experts usually use their experiential judgment when making the decision [7] Procedure to determine the weight to design factors [13], are:

(1) Determine each factor percentage to distinguish the weight.

(2) Assign the least important factor from step 1 and assume the importance scale among the objective is linear.

(3) The importance of factor should be ranked from 1 to 5, where 1 represents the least important factor and 5 is the most important.

Table 9. Factor weight

\begin{tabular}{lc}
\hline Parameter & Weight \\
\hline Land Cover (LC) & 5 \\
Rainfall (R) & 4 \\
Drainage Density (DD) & 3 \\
Slope (S) & 2 \\
Land Subsidence (LS) & 1 \\
\hline
\end{tabular}

Ranking on the five flood vulnerability parameters is as shown in Table 10 The ranking is based on a Pairwise Comparison matrix analysis. The result of the matrix in Table 10. Weighted comparison for all factors and parameters are shown in Table 15.

Table 10. Ranking of flood vulnerability parameters

\begin{tabular}{lccccc}
\hline Criteria & LC & R & DD & S & LS \\
\hline LC & 1 & 2 & 3 & 4 & 5 \\
R & 0.50 & 1 & 2 & 3 & 4 \\
DD & 0.33 & 0.50 & 1 & 2 & 3 \\
S & 0.25 & 0.33 & 0.50 & 1 & 2 \\
LS & 0.20 & 0.25 & 0.33 & 0.50 & 1 \\
\hline
\end{tabular}

Table 11. Weighted comparison table

\begin{tabular}{lccccccc}
\hline Criteria & LC & R & DD & S & LS & Priority & Percent \\
\hline LC & 0.44 & 0.49 & 0.44 & 0.38 & 0.33 & 0.416 & 42 \\
R & 0.22 & 0.24 & 0.29 & 0.29 & 0.27 & 0.262 & 26 \\
DD & 0.15 & 0.12 & 0.15 & 0.19 & 0.20 & 0.161 & 16 \\
S & 0.11 & 0.08 & 0.07 & 0.10 & 0.13 & 0.099 & 10 \\
LS & 0.09 & 0.06 & 0.05 & 0.05 & 0.07 & 0.062 & 6 \\
\hline Total & 1.00 & 1.00 & 1.00 & 1.00 & 1.00 & 1.00 & 100 \\
\hline
\end{tabular}

The final result of calculation obtained by Consistency Index (CI) of 0.0222 and Random Index (RI) for 5 (five) parameter is 1.12. Maximum allowed values for CI and $\mathrm{RI}$ are $\mathrm{CI} \leq 0.1$ and $\mathrm{CR} \leq 10 \%$. In this study obtained $\mathrm{CI}$ value of $0.0222(\mathrm{CI} \leq 0.1)$ and $\mathrm{CR}$ of $1.99 \%(\mathrm{CR} \leq 10 \%)$ so that the $\mathrm{CI}$ and $\mathrm{CR}$ values meet the maximum permissible standards. The values are as follows:

$$
\begin{aligned}
& \text { Lambda }(\lambda) \quad=5.09 \\
& \mathrm{~N} \quad=5 \\
& \text { RI }=1.12 \\
& \text { CI }=0.0222 \\
& \mathrm{CR} \quad=0.0199(1.99 \%)
\end{aligned}
$$

Since CR is less than $10 \%$, the ratio indicates that the consistency is reasonable in this analysis, and this implies that the specified weight is acceptable.

Once the weight in each factor was determined, the multi-criteria analysis was performed to produce a floodvulnerable area by using the GIS approach. To compute the vulnerable area, a weight linear combination was applied as shown in equation:

\section{$Z=(0.416 x$ Land Cover $)+(0.262 x$ Rainfall $)+(0.161 x$ Drainage Density $)+(0.099 \times$ Slope $)+(0.062 x$ Land Subsidence)}

The results of flood vulnerability mapping in the mainland area of Sidoarjo Regency are as shown in Figure 9. The vulnerability of flood areas is categorized into 5 (five) criterias, namely "Very high vulnerable", "High vulnerable", "Moderate vulnerable", "Low vulnerable", and "Very low vulnerable".

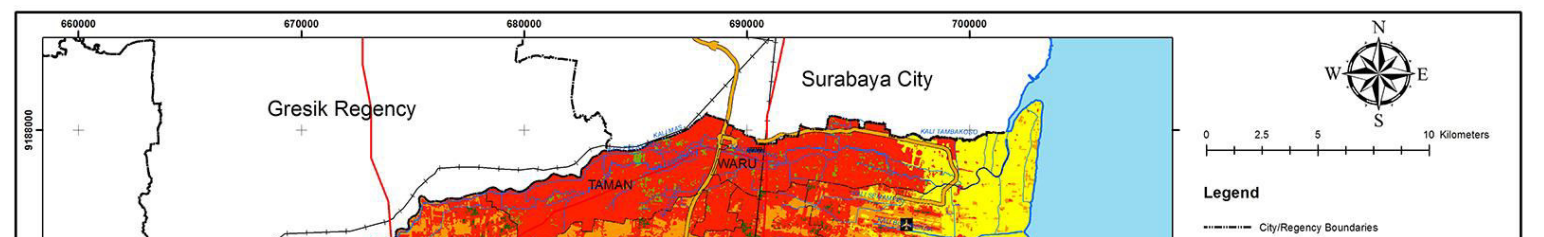




\section{CONCLUSIONS}

It is very difficult to reduce the natural disaster especially flood. Flood vulnerability identification with using remote sensing and GIS could be a consideration in regional planning and its policy making. So that in the future hopefully could lower the effect caused by the disaster.

From this research can be concluded as follows:

1. In order to analyse flood vulnerability area in Sidoarjo Regency, a GIS and remote sensing-based map was created, consist of certain parameters such as land cover, rainfall, drainage density, slope, and land subsidence;

2. Most of Sidoarjo regency is flood vulnerable area, which is $76.24 \%$ or $658,702,719.91 \mathrm{sqm}$. It consist of $33.14 \%$ very high vulnerable area and $43.10 \%$ high vulnerable area.

3. Very high vulnerable flood-prone areas in Sidoarjo Regency include most area of Jabon, Porong, Tanggulangin, Balongbendo, Krembung, Taman, and Waru sub-districts, while others are some parts of Candi, Sidoarjo, Buduran, and Gedangan subdistricts. High vulnerable flood-prone area include Tarik, Prambon, Tulangan, Wonoayu, and Sukodono sub-districts.

4. The most dominant factors causing flooding in Sidoarjo Regency is the change of land cover, heavy rainfall, and high drainage density, while other factor also contributing to future flood vulnerability are land subsidence.

\section{REFERENCES}

[1.] Balai Besar Wilayah Sungai Brantas, "Lima Pilar BBWS Brantas", Surabaya, Indonesia, 2011

[2.] Badan Nasional Penanggulangan Bencana,“ Data dan Informasi Bencana Indonesia”, 2016. Available at: http://dibi.bnpb.go.id/data-bencana. Accessed 17 November 2016.
[3.] Berita Jatim, "Banjir Porong Terus Naik, BPLS Tambah Pompa Sedot Air", 2016. Available at: http://beritajatim.com/peristiwa/259315/banjir_porong_te rus_naik, bpls_tambah_pompa_sedot_air.html

[4.] Udani, P.M. and Mathur D.K., " Flood Hazard Vulnerability Mapping Using Remote Sensing \& GIS: A Case Study Along the Villages of Anand Taluka", Pelagia Research Library, advances in Applied Science Research, 2016, 7(3): 214-221

[5.] Elkhrachy, Ismail ,"Flash Flood Hazard Mapping Using Satellite Images and GIS Tools: A Case Study of Najran City, Kingdom of Saudi Arabia (KSA)". The Egyptian Journal of Remote Sensing and Space Sciences. Vol. 18, 2015, pp. 261-278.

[6.] Haryanto, T., C. B. Pribadi, U. W. Defiantari, H. Hidayat, A. Kurniawan, M. Yusfania, A. Basofi dan M. Hamza 2016. "Kajian Penurunan Tanah Di Kawasan Tanggulangin Dan Sekitarnya Kabupaten Sidoarjo (Kelurahan Kalidawir, Kelurahan Banjarasri, dan Kelurahan Kedungbanteng)". Pusat Studi Kebencanaan Lembaga Penelitian dan Pengabdian Kepada Masyarakat Institut Teknologi Sepuluh Nopember, Surabaya.

[7.] Rimba, Andi Besse; Setiawati, Martiwi Diah; Sambah, Abu Bakar; and Miura, Fusanori. (2017). "Physical Flood Vulnerability Mapping Applying Geospatial Techniques in Okazaki City, Aichi Prefecture, Japan". Urban Science. Vol. 1, No. 7, hal. 1-22.

[8.] BMKG (2010). "Kondisi Cuaca Ekstrem dan Iklim Tahun 2010-2011". Badan Meteorologi Klimatologi dan Geofisika. (BMKG). http://data.bmkg.go.id/Share/Dokumen/press\%20release $\% 20$ kondisi\%20cuaca\%20ekstrim\%20dan\%20iklim\%20t ahun\%202010-2011.pdf

[9.] Anderson, J. R., Hardy, E.E., Roach, J.T., dan Witmer, R.E. (1976), "A Land Use and Land Cover Classification System for Use With Remote Sensor Data". Geological Survey Professional Paper 964. United States Government Printing Office, Washington.

[10.] Geokov. Geokov Education. Available online at http://geokov.com/education/slope-gradienttopographic.aspx (accessed on 15 March 2017) 
[11.] Haynes, R.H. (1998). The Canadian System of Soil Classification, 3rd ed.; NRC Research Press: Ottawa, ON, Canada.

[12.] Kodoatie Robert J. dan Sugiyanto, "Banjir: Beberapa Penyebab dan Metode Pengendaliannya Dalam Perspektif Lingkungan", Gadjah Mada University Press, Yogyakarta, 2002.
[13.] Saaty, Thomas L. (2008). "Decision making with the analytic hierarchy process". International Journal of Services Sciences, Vol. 1, No. 1, hal. 83-98.

[14.] Saaty, Thomas L. (1990). "How to make a decision: The Analytic Hierarchy Process". European Journal of Operational Research, Vol. 48, hal. 9-26. 